\title{
橋本病における甲状腺機能の経年変化と 抗甲状腺抗体（TGHA，MCHA）について
}

\author{
昭和大学藤が丘病院内科内分泌代謝科 \\ 伊藤病院* \\ 大阪市立大学医学部第二内科** \\ 長谷川真, 飯 野史 郎 \\ 伊藤國 彦，浜田昇※*
}

The Clinical Course of Hashimoto's Thyroiditis during

a 5 year Observation Period in Relation to the Change in Thyroid Function and the Titers of the Antithyroid Antibody

\section{Makoto Hasegawa, Shiro Iino, Kunihiko Ito*, Noboru Hamada**}

\author{
Division of Endocrinology and Metabolism, Department of Internal \\ Medicine, Showa University Fujigaoka Hospital, Yokohama, Japan, \\ and *Ito Hospital, Tokyo, Japan \\ **Second Department of Internal Medicine, \\ Osaka City University, Osaka, Japan
}

In order to discover whether or not thyroid function in patients with Hashimoto's disease will move toward hypothyroidism with age, we investigated the thyroid function and antithyroid antibody titers at the initial examination and 5 years later in 181 patients with goitrous Hashimoto's thyroiditis. Pregnant patients and those within 1 year of the postpartum period were excluded. The thyroid function was assessed before medication or at least one month after stopping it. At the initial examination, 52\% (94 cases) of the cases were euthyroid, 24\% (44 cases) were subclinically hypothyroid and 24\% (43 cases) were hypothyroid. It was not observed whether the incidence of hypothyroidism tended to be greater in older patients or in patients with longer duration of illness. Five years later, 68\% of euthyroid patients at the initial examination remained in euthyroid state, $18 \%$ had become subclinically hypothyroid, and 9\% were hypothyroid. The thyorid function was not evaluated in $5 \%$ of the patients because they were under treatment with 1 -thyroxine. In the patients with subclinical hypothyroidism at the initial examination, $30 \%$ had become euthyroid, 23\% remained subclinically hypothyroid, 32\% had become hypothyroid and 16\% were not evaluated. Thirty percent of the patients with hypothyroidism at the initial examination had become euthyroid, $7 \%$ were subclinically hypothyroid, $28 \%$ remained hypothyroid and $35 \%$ were not evaluated. The higher the titer of TGHA, the higher the 
percentage of hypothyroidism at the first examination. A similar but much stronger tendency was observed in the patients with a higher titer of MCHA. In the patients with a higher titer of TGHA, the number of hypothyroid patients approximately doubled after 5 years, although such a tendency was not observed in the patients with a higher titer of MCHA. In patients with persistent hypothyroidism, the age was significantly higher, the serum concentration of $\mathrm{T} 3$ lower and the titer of TGHA at the initial examination and MCHA 5 years later higher than in the patients with transient hypothyroidism. The titer of MCHA was significantly decreased 5 years later in patients with transient hypothyroidism.

From these results, it is indicated that in patients with goitrous hypothyroidism, the incidence of hypothyroidism was higher in the cases with high titers of antithyroid antibody than in those with low titers, and that in the patients with transient hypothyroidism, the age was lower, the serum level of T3 higher and the titer of TGHA lower than in the cases with permanent hypothyroidism. It was concluded that the thyroid function in Hashimoto's thyroiditis does not consistently move toward the hypothyroid range, but it sometimes recovers even from the hypothyroid state, and that there are certain close relations between the thyroid function and the titers of TGHA and MCHA, although they are similar but quite different from one another.

\section{は じめに}

甲状腺腫を有する橋本病（goitrous Hashimoto's thyroiditis：以下GHT）の甲状腺機能がど のような自然経過をたどるかについては，今日なお十分明らかでない。GHT を長期間観察した研 究では，本症の甲状腺機能は徐々に機能低下症に向かって進むとする報告5)152121 が多い。しかし，小 児 ${ }^{18)}$ や出産後 ${ }^{22}$ の GHT における如く，甲状腺機能低下症が一過性におこる場合があることもよく 知られた事実で, 出産と関係のない成人 GHT の一過性甲状腺機能低下症の症例も報告されてい $3^{10191228)}$ 。さらに，組織学的な経過について検討した報告では，増悪傾向はほとんどないか，あっ てもごくわずかであるとされている725)。以上のごとく，GHT の経過についての報告はさまざま であるが，一度に 100 人を越える多数の GHT 患者について一定の期間経過を観察した報告はない。 そこで, 著者らは初診時に GHT と診断され，甲状腺機能および抗甲状腺抗体を測定した患者で， 5年以後に再び同様の検査を施行しえた181例について，これらの検査所見の推移を検討し，興味あ る結果を得たので報告する。

\section{対象，目的ならびに方法}

対象は1976年に初めて伊藤病院を受診し，甲状腺機能抒よび抗甲状腺抗体を検査した初診時未治 療の GHT 患者で, 妊娠中および出産後一年未満の症例を除いた 396 例のうち，5年以後に再び同 様の検査を施行し得た 181 例 [男5例, 女176例 ; 平均年齢 41 歳（7～71歳）] である。 5 年以後の検 査時に当院に通院していなかった患者については, 全例に葉書で来院を促した。これにより45人が 来院し, 検査を受けた。

GHT の診断は，バセドゥ病以外のびまん性甲状腺腫を有する患者で，かつ次の三つの条件 
［1）抗甲状腺抗体陽性（MCHA > $100 \times$ または TGHA > $100 \times ） ， 2 ）$ 穿刺吸引細胞診で橋本病の 所見を有する，3）成人発症の甲状腺機能低下症で甲状腺治療の既往がない]のうちのいずれか一 つ以上を満足するものとした。また， 5 年間の経過中に，他の甲状腺疾患や自己免疫疾患を発症し た症例は除外した。甲状腺機能の判定は, 血清 $\mathrm{T}_{4}$ 值および血清 TSH 值が正常であるものを Euthyroidism (E)，血清 $\mathrm{T}_{4}$ 值が正常で血清 TSH 值が高值の症例を Subclinical Hypothyroidism （SH），血清 $\mathrm{T}_{4}$ 值が低值かつ血清 TSH 值が高值の症例を Hypothyroidism（H）とした。また， 5 年以後の甲状腺機能のチェックは，1- $T_{4}$ を服用中の患者は原則として1ヶ月以上服薬を中止させ て検査を行ったが，その間に機能低下症のため，服薬を開始した症例は $\mathrm{H}$ と判定した。巨大甲状 腺腫や患者自身の都合（拒否）により服薬を中止できなかった症例については，1-T 4 を服薬中に もかかわらず TSH が高值であれば $\mathrm{H}$ と判定し, TSH 值が正常であれば判定不能（U）と した。

上記の対象について，対象が平均的な GHT の集団であるか否か，また，GHT の甲状腺機能 が加齢とともに甲状腺機能低下症に向からか否かを調べるため, まずはじめに，対象例の年齢分布 と年代別の甲状腺機能を調べ，さらに甲状腺腫に気付いた時から初診時までの月数（病悩期間）と 甲状腺機能との関係について検討した。つぎに，初診時と 5 年後の甲状腺機能状態を比較検討した。 また，初診時の TGHA 抗体価および MCHA 抗体価と初診時および5年後の甲状腺機能との関係 についても検討した。つぎに, 初診時にみられた甲状腺機能低下が永続的か否かを調べるため, 初診時から 5 年後の検査時まで甲状腺機能低下症が持続していた例（永続的甲状腺機能低下症：

$\mathrm{PH}$ 群）と初診時には甲状腺機能低下症であったが5年後には甲状腺機能が正常となっていた例 （一過性甲状腺機能低下症：TH 群）について年齢, 病悩期間, 血清 $\mathrm{T}_{4}$ 值, 血清 $\mathrm{T}_{3}$ 值, 血清 $\mathrm{TSH}$ 值，抗甲状腺抗体価（初診時ならびに5年後）を比較した。

血清 $\mathrm{T}_{4}$ 濃度の測定には，1976年はテトラソルブ（ダイナボット）（N； $5 \sim 13 \mu \mathrm{g} / \mathrm{dl} ）$ を，1981 年は $\mathrm{T}_{4}$ リアキット (ダイナボット) $\left(\mathrm{N} ; 5 \sim 13 \mu \mathrm{g} / \mathrm{dl}\right.$ ) を, 血清 $\mathrm{T}_{3}$ 濃度の測定には $\mathrm{T}_{3}$ リアキッ トII（ダイナボット）（N；80～180ng/dl）を使用した。血清 TSH 濃度の測定には，1976年

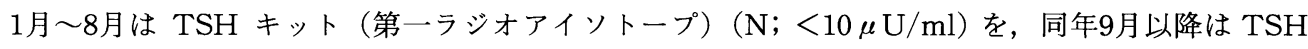
リアキット I （ダイナボット）（N；<5 $\mu \mathrm{U} / \mathrm{ml} ） を ， 1981$ 年は TSH リアキットIIを使用した。 抗マイクロゾーム抗体および抗サイログロブリン抗体は，それぞれマイクロゾームテスト（MCHA） （富士藏器）およびサイロイドテスト（TGHA）（富士臟器）により抗体価を測定した。

統計は頻度の差の検定には $\chi^{2}$ 検定を使用し，平均値の差の検定には $\mathrm{t}$ 検定を使用した。

\section{結 果}

\section{GHT の甲状腺機能と年齢および病悩期間との関係}

GHT 患者の年齢別分布と各年代における E, SH，H の比率は，Fig. 1に示す如くで，患者数 は加歯とともに増加し，40歳台をピークとしてその後減少していく傾向が認められた。20歳以上の 46\%に $\mathrm{TSH}$ 高值 $(\mathrm{SH}+\mathrm{H})$ が認められ， $\mathrm{T}_{4}$ 值まで低下した $\mathrm{H}$ の比率は約 $20 \%$ でった。また， 加歯にともない $\mathrm{H}$ の比率が高くなるといった傾向は認められなかった。19歳以下の患者では, 有意ではないが $\mathrm{H}$ の比率は他の年代よりも高く, 53\%であった。

甲状腺機能と病悩期間との関係は, Fig. 2示すごとくで, 特に病悩期間が長いほど $\mathrm{H}$ の比率 が高くなる傾向は認められなかった。むしろ, 病悩期間の長い患者では $\mathrm{H}$ の比率は低い傾向が 認められた。 


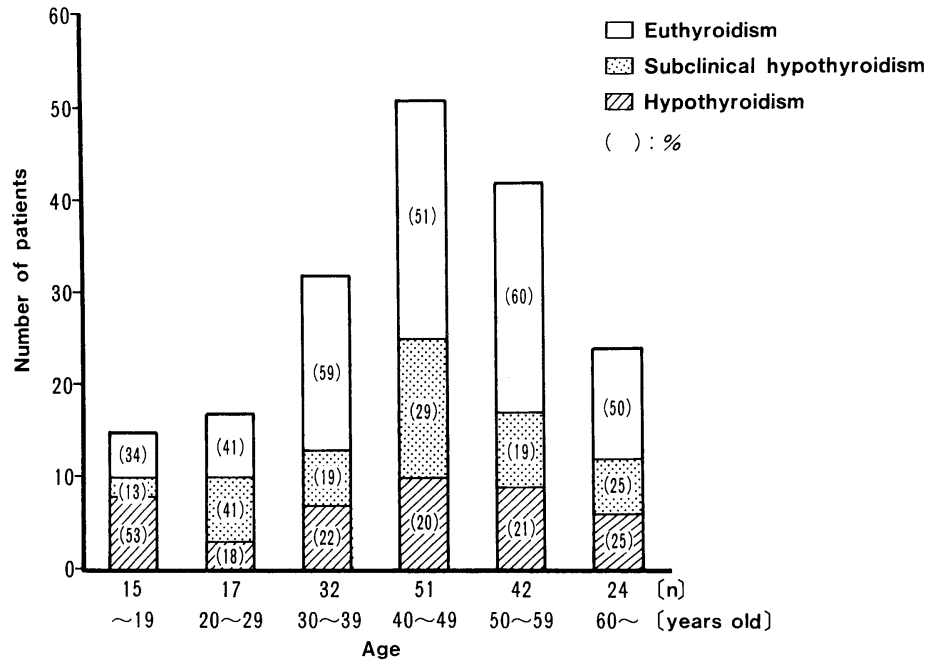

Fig. 1. Age-specific incidence of Hashimoto's thyroiditis and percentage of various thyroid states.

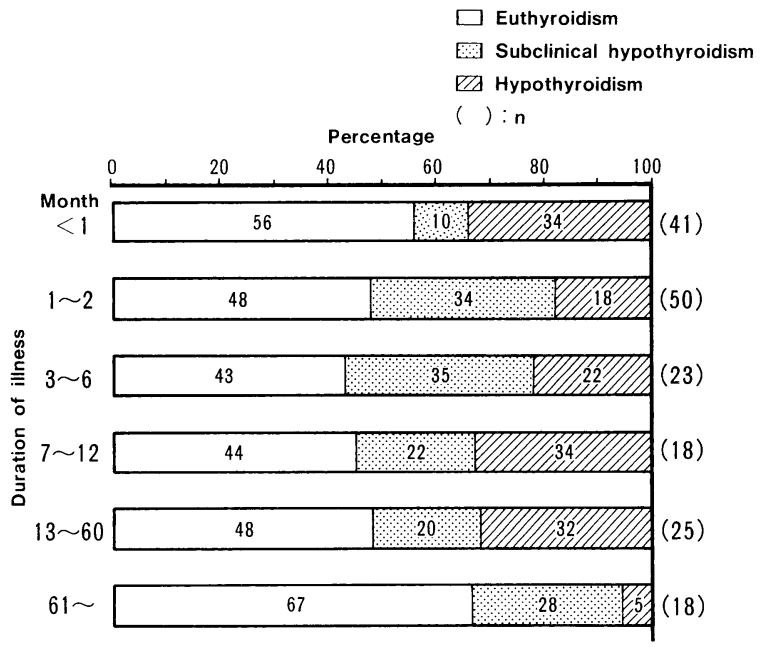

Fig. 2. Relationship between duration of illness and thyroid function in the patients with Hashimoto's thyroiditis.

\section{GHT 患者における初診時の甲状腺機能とその5年後の甲状腺機能について}

全症例181例の初診時の甲状腺機能は94例（52\%）がE，44例（24\%）がSH，43例（24\%）が H

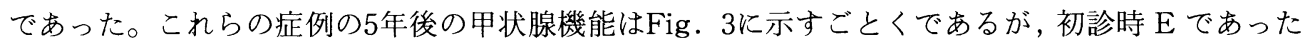
群の5年後の甲状腺機能は， $68 \%$ が $\mathrm{E}$ のままで， $18 \%$ が $\mathrm{SH}$ に，9\%が $\mathrm{H}$ となった。初診時

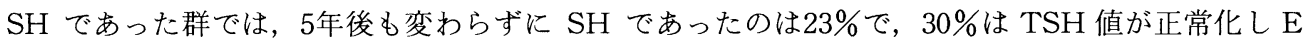
となり, 同時に $32 \%$ は $\mathrm{T}_{4}$ 值が低下して $\mathrm{H}$ となった。初診時 $\mathrm{H}$ の群では, 5 年後に U の症例が $35 \%$ と多く，甲状腺機能の変化を正確に把握することは困難であったが，すくなくとも $30 \%$ が

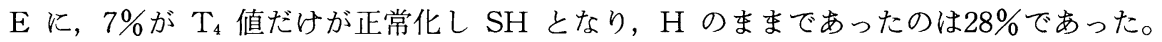




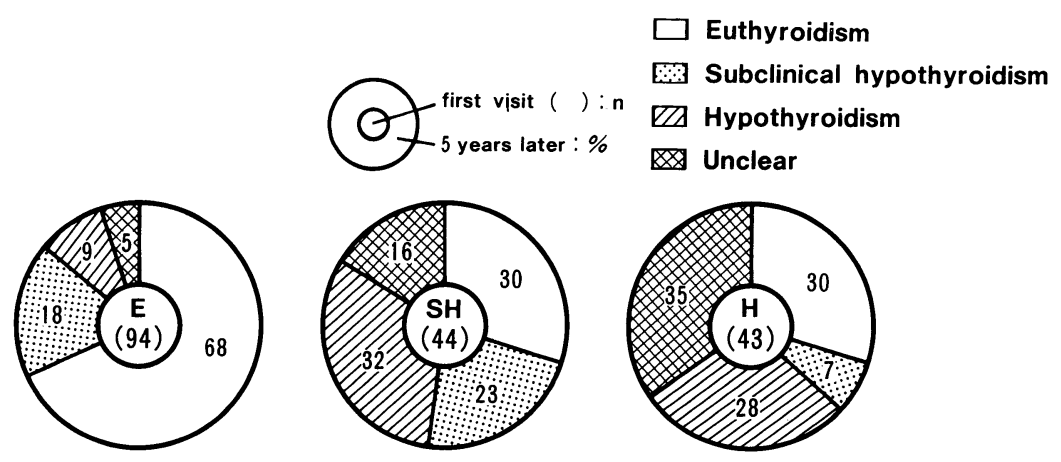

Fig. 3. Thyroid functions at the first visit and 5 years later in the patients with Hashimoto's thyroiditis.

Unclear indicates the patients whose thyroid function were not determined because of being under treatment of l-thyroxine.

\section{GHT の甲状腺機能と抗甲状腺抗体価の関係について}

\section{1) TGHA 抗体価と甲状腺機能}

初診時の TGHA 抗体価と初診時の甲状腺機能との関係をFig. 4左に, 初診時 TGHA 抗体価 と5年後の甲状腺機能との関係をFig. 4右に示した。初診時の E, SH, H の比率は, 全体として 抗体価が高くなるほど, $\mathrm{E}$ は減少し, $\mathrm{SH}$ および $\mathrm{H}$ は増加する傾向が認められた。初診時の $\mathrm{E}$ の比率は, 抗体価の高いもので有意に低かったが, H の比率は抗体価の高いものでは高い傾向が みられたが有意の差はなかった。初診時の抗体価別に分けた各群の初診時と5年後の甲状腺機能を 比較すると, 抗体価の低い群と抗体価が中等度陽性の群では, 初診時と 5 年後でほとんど差は認め られなかった。しかし, 抗体価が強陽性を示した群では, Uの比率が高いために明らかではない が，E の頻度は低くなっており，H の頻度は増加（p<0.05）しているのが認められた。

[first visit)

[5 years later]
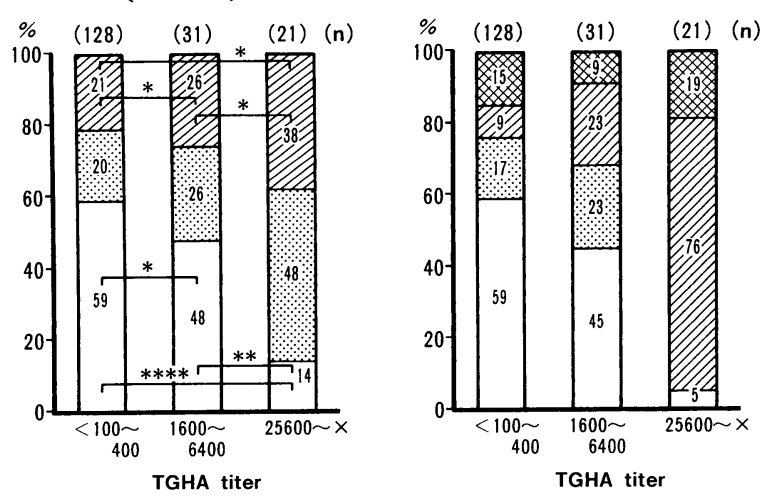

Fig. 4. Relationships between antithyroglobulin antibody (TGHA) titer at the first visit and thyroid states at the first visit (left) or 5 years later (right) in the patients with Hashimoto's thyroiditis.

$*:$ N.S., $* *: \mathrm{P}<0.05, * * * *: \mathrm{P}<0.001$

$\square:$ Euthyroidism, $⿴$ : Subclinical hypothyroidism

西: Hypothyroidism, : Unclear 


\section{2） $\mathrm{MCHA}$ 抗体価と甲状腺機能}

Fig. 5左に初診時の MCHA 抗体価と初診時の甲状腺機能を, Fig. 5右に初診時の MCHA 抗体価と 5 年後の甲状腺機能の関係を示す。初診時の $\mathrm{E}, \mathrm{SH}, \mathrm{H}$ の比率は TGHA の場合と同様 に，抗体価の上昇とともに $\mathrm{H}$ が増加し， E が減少する傾向を示した。 $\mathrm{H}$ の増加傾向および $\mathrm{E} の$ 隇少傾向は TGHA の場合よりも明らかであり, 有意の差が認められた。初診時の MCHA 抗体 価で分けた各群の初診時と 5 年後の $\mathrm{E}, \mathrm{SH}, \mathrm{H}$ の比率を比較すると, 5 年後には抗体価の低い群で も $\mathrm{H}$ の増加と $\mathrm{E}$ の減少が認められた。抗体価が中等度陽性の群では，U を考慮した場合初診時 と5年後に大きな相違は認められなかった。しかし, MCHA 抗体価の高い症例では TGHA 抗体 価の高い例のような明らかな $\mathrm{H}$ の増加は認められず, 逆に $\mathrm{E}$ が増加しているのが認められた。

4. 永続的甲状腺機能低下症 (PH) ならびに一過性甲状腺機能低下症 (TH) を示す GHT の比較 対象例のうち $\mathrm{PH}$ 例は 12 例, TH 例は 13 例認められた。これらの症例について初診時の年齢, 病悩期間, 血清 $T_{4}$ 值, 血清 $T_{3}$ 值, 血清 TSH 值および初診時と5年後の抗甲状腺抗体価を比較 した（Table 1, Fig. 6) 。平均年齢は PH 群が49.3歳，TH 群が28.6歳で PH 群が有意に高齢 であった。平均病悩期間は $\mathrm{PH}$ 群が17.9ヶ月, TH 群が7.3ヶ月であったが S.D. が大きく有意 差は認められなかった。初診時の平均血清 $\mathrm{T}_{4}$ 值は $\mathrm{PH}$ 群が $2.7 \mu \mathrm{g} / \mathrm{dl}, \mathrm{TH}$ 群が $3.4 \mu \mathrm{g} / \mathrm{dl}$ で有 意差はなかったが, 平均血清 $\mathrm{T}_{3}$ 值は $\mathrm{PH}$ 群が67.5ng/dl, $\mathrm{TH}$ 群が102.9ng/dl で $\mathrm{TH}$ 群が有 意に高い傾向を示した。平均血清 TSH 值は $\mathrm{PH}$ 群が $114.6 \mu \mathrm{U} / \mathrm{ml}$, TH 群が $137.8 \mu \mathrm{U} / \mathrm{ml}$ で 有意差は認められなかった。抗甲状腺抗体は, Fig. 6に示すごとく, dilution factor としての抗 体価が $4^{6} \times 100 \times \sim 4^{0} \times 100 \times$ および<100×の8段階まで, 高いものから順次, 8, 7, 6, 5, 4, 3, 2, 1 といらスコアで表現し，これを用いて $\mathrm{t}$ 検定を行った。初診時には，TGHA 抗体価は PH 群で TH 群より明らかに高かったが，MCHA 抗体価は両群間に有意差は認められなかった。5年後の 抗体価は, TGHA, MCHA ともに有意に PH 群において高い傾向が認められた。初診時と 5 年後 を比較すると, TH 群では TGHA 抗体価の変動は認められなかったが, MCHA 抗体価は有意に
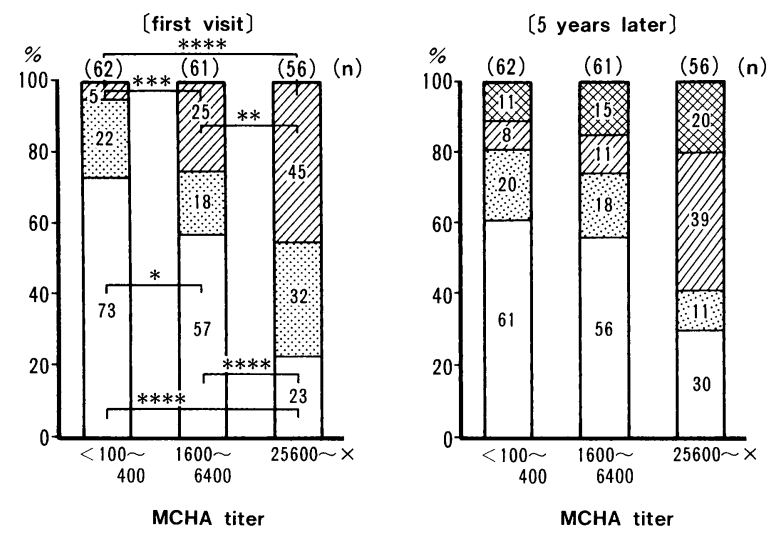

Fig. 5. Relationships between antimicrosomal antibody (MCHA) titer at the first visit and thyroid states at the first visit (left) and 5 years later (right) in the patients with Hashimoto' s thyroiditis. $*:$ N.S. , **: $\mathrm{P}<0.05, * * *: \mathrm{P}<0.01, * * * *: \mathrm{P}<0.001$

$\square:$ Euthyroidism, $\quad$ : Subclinical hypothyroidism

ש : Hypothyroidism, Unlear. 
低下した。TGHA 抗体価においては差は認められず, PH 群では TGHA, MCHA ともに明らか な抗体価の変化は認められなかった。

Table 1. Comparison of clinical data between permanent and transient hypothyroid patients with Hashimoto's thyroiditis.

\begin{tabular}{|c|c|c|c|c|c|c|}
\hline & & $\begin{array}{c}\text { Age } \\
\text { (yrs. old) }\end{array}$ & $\begin{array}{l}\text { Duration of } \\
\text { illness } \\
\text { (month) }\end{array}$ & $\begin{array}{c}\mathbf{T}_{4} \\
(\mu \mathrm{g} / \mathrm{dl})\end{array}$ & $\begin{array}{c}\mathrm{T}_{3} \\
(\mathrm{ng} / \mathrm{dl})\end{array}$ & $\begin{array}{c}\text { TSH } \\
(\mu \mathrm{U} / \mathrm{ml})\end{array}$ \\
\hline $\begin{array}{l}\text { Permanent } \\
\text { Hypothyroidism } \\
\text { (PH) } \\
(n=12)\end{array}$ & $\begin{array}{l}\text { Mean } \\
\text { S.D. } \\
\text { Range }\end{array}$ & $\begin{array}{c}49.3 \\
10.7 \\
34 \sim 70\end{array}$ & $\begin{array}{c}17.9 \\
36.9 \\
0.4 \sim 133\end{array}$ & $\begin{array}{c}2.7 \\
1.3 \\
0.8 \sim 4.9\end{array}$ & $\begin{array}{r}67.5 \\
31.6 \\
30 \sim 110\end{array}$ & $\begin{array}{c}114.6 \\
96.5 \\
33.8 \sim 300\end{array}$ \\
\hline $\begin{array}{l}\text { Transient } \\
\text { Hypothyroidism } \\
\text { (TH) } \\
(n=13)\end{array}$ & $\begin{array}{l}\text { Mean } \\
\text { S.D. } \\
\text { Range }\end{array}$ & $\begin{array}{l}28.6 \\
19.5 \\
8 \sim 57\end{array}$ & $\begin{array}{r}7.3 \\
13.4 \\
0.1 \sim 36\end{array}$ & $\begin{array}{c}3.4 \\
1.1 \\
1.4 \sim 4.9\end{array}$ & $\begin{array}{r}102.9 \\
30.6 \\
50 \sim 175\end{array}$ & $\begin{array}{c}137.8 \\
115.8 \\
32.6 \sim 300\end{array}$ \\
\hline$P$ value & & $<0.005$ & N.S. & N.S. & $<0.002$ & N.S. \\
\hline
\end{tabular}

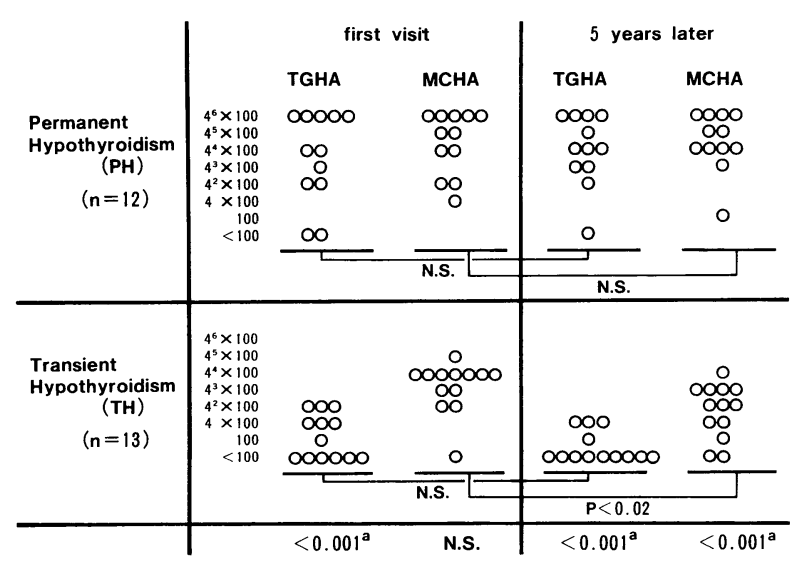

Fig. 6. Titers of antithyroid antibodies (TGHA, MCHA) at the first visit and 5 years later in permanent or transient hypothyroid patients with Hashimoto's thyroiditis.

"a" indicates significant difference between permanent and transient hypothyroidism.

\section{考案}

Saxena らは, 小児の GHT 32例の経過観察から, 小児では約半数が機能低下症に移行すると 報告し ${ }^{21)}$, Gordin らは無症候性自己免疫性甲状腺炎患者22例の経過観察で, 本症の7.3\%が，また 初期に TSH の上昇があれば $26 \%$ が毎年甲状腺機能低下症に陥ると述べている5)。さらに, Papapetorou らは，12例の GHT に 1-T $T_{4}$ を投与し，6１2年後に服薬を中止させて検査したところ， 
全例が甲状腺機能低下症になったことから，初診時に甲状腺機能が正常であってもろ胞の破壊は進 行し, 初診時から機能低下症の患者では病気の活動性がそのまま持続しているとした。そして, GHT 患者の甲状腺機能低下症を未然に防ぐためには，甲状腺機能が正常であっても，一生甲状腺ホルモ ン剤を服用すべきであると報告している ${ }^{15)}$ 。以上の如く，GHT は不可逆的な疾患で，しかも， その甲状腺機能状態は徐々に機能低下へ向かっていくと考えられてきた。もし，GHT の甲状腺機 能が，ある一定の速さで甲状腺機能低下症に向からと仮定すれば，当然，高㱓者汪ど，また病脳期 間が長いほど甲状腺機能低下症の頻度は增えるはずである。しかし, 我々の成績では, 本症に抒け る甲状腺機能低下症の比率は加齢や病悩期間と関係なく, 一度甲状腺機能低下症に陥ってもかなり の頻度（30\%以上）で回復することが示された。

GHT における甲状腺機能低下症が回復する場合があることは事実で，小児期18 や，出産後の GHT 患者の中に稀ならず一過性の甲状腺機能の低下がおこることも報告されている(2)。また， 成人の GHT でも出産に関係なく一過性甲状腺機能低下症がおろることを認めた症例報告もあ $\eta^{10191228)}$, 組織学的な経過観察では, 必ずしも進行性変化を示すとは限らないとする報告 ${ }^{725)}$ も認め られる。しかし，100例を越える多数の GHT を集めて一定期間経過観察した報告は，我々が検索 した限りにおいてはない。そして，成人の GHT の甲状腺機能が可逆性であることを示唆する報 告は，甲状腺機能低下症の GHT 患者を無治療で3〜20週観察し，27例中14例が可逆的であったと する Yosinari らの報告を認めるのみである ${ }^{30}$ 。

GHT の自然経過についての報告がさまざまである理由として次のことが考觉られる。第一に， GHT の病態が多様であるために, 研究の対象の数が少なすぎることである。そのため, 対象があ る選択を受けた橋本病の集団となってしまった可能性がある。第二として，一旦甲状腺機能低下症 に陷った後の甲状腺機能に対する検討がほとんどおこなわれていないことである。今回の研究の 対象は, 1976年に伊藤病院を初診した未治療 GHT 患者全例396例の年齢分布（示していない）や 各甲状腺機能の比率と比較し, また, 厚生省特定疾患橋本病調査研究班の 1423 例の年齢分布 ${ }^{23}$ と 比較してみて，日本における病院を訪れる GHT 患者の集団にほぼ一致していると考えられた。

GHT といら疾病にとっては5年間といら観察期間は極めて短い時間であり, 今回の結果から GHT の真の自然経過を推測することは困難であるにしても，成人の GHT の甲状腺機能低下症 の中に永続的な甲状腺ホルモン剤投与をおこなら必要のない症例が少なからず含まれていることは 想像にかたくない。

GHT における甲状腺機能の低下が何に起因するかは現在でもまだなお，十分明らかでない。 自己免疫による甲状腺ろ胞の破壊がその一因を担っていることはまず間違いないが, GHT におけ る甲状腺機能の低下は組織の破壊だけでは説明しきれるものではなく, 例えばョード摄取の影響や， 甲状腺上皮細胞内のヨード有機化機転を含む甲状腺ホルモン生合成過程に括ける機能的な障害 ${ }^{27}$ な どについても考慮しなければならない。最近, マイクロゾーム抗原が甲状腺ペルオキシダーゼ (TPO) そのものであることがわかってきた ${ }^{16)}$ が，MCHA が抗 TPO 抗体であるとすれば，甲状 腺機能低下症における甲状腺ろ胞破壊以外の機能的な起序に対する抗甲状腺抗体の関与を考える5 えでも非常に興味深い。

GHT において抗甲状腺抗体が甲状腺機能低下に対してどのような役割を果たしているのか統一 した見解は得られていない。しかし，甲状腺組織障害についての in vitro の結果 ${ }^{17226)}$ や本抗体が 炎症反応の結果できた新しい抗原に対する抗体とは考えにくいとする Aho らの結果 ${ }^{1)}$ ，さらに 
$\mathrm{MCHA}$ と甲状腺組織へのリンパ球浸潤とが相関すること年20311 などから，抗体が甲状腺機能低下に 直接かかわっているといら見解が有力である。抗甲状腺抗体価と甲状腺機能との関係については, Hawkins らは，MCHA 抗体価はTSH 上昇の予測に有用であるとし ${ }^{8}$, Tunbridge らも TGHA

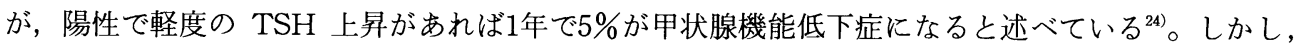
彼等の対象は，一見健常人であり，健常人から無症候性慢性甲状腺炎を区別するための手段として 抗甲状腺抗体が使われているにすぎない。例外的に出産後の GHT ${ }^{3)}$ や silent thyroiditis におけ る一過性甲状腺機能低下症では MCHA 抗体価が上昇することが報告されている ${ }^{29}$ が，抗甲状腺抗 体と GHT の甲状腺機能の相関性については，これを認めるもの614) と認めないものがある ${ }^{11222}$ 。 抗体価と甲状腺機能の予後とには関係がないとされている ${ }^{12)}$ 。我々の成績では, 初診時の甲状腺機 能は TGHA, MCHA ともに抗体価が高いほど甲状腺機能低下症の比率が高く, 甲状腺機能正常 者の比率が低くなるが，その傾向は MCHA においてより有意であった。しかし，同一対象にお ける5年後の甲状腺機能は，TGHA 抗体価で分けた群ではその傾向はより顕著となったが，MCHA 抗体価で分けた群では抗体価の低い群でも甲状腺機能低下症が増加し，高抗体価群でも甲状腺機能 正常者が初診時より増加したため, 抗体価が高くなるにつれて甲状腺機能低下症が増えるという 傾向は初診時ほど明らかではなくなった。このことは，MCHA 抗体価がその時点の甲状腺機能と 強く関係するのに比べ TGHA は予後の甲状腺機能とより強く関係することを示すものであると 考兄られた。

甲状腺機能低下症が一過性か永続性かを鑑別するため各種のパラメーターを比較した報告では， 一過性甲状腺低下症患者においては ${ }^{131} \mathrm{I}$ 摂取率が比較的高いのが認められるといら ${ }^{30}$ 。我々の結果 では，一過性の甲状腺機能低下症患者は，永続的甲状腺機能低下症に比べ若年者で， $\mathrm{T}_{3}$ 值が高く， TGHA 抗体価は初診時も5年後も低值で, 5 年後の MCHA 抗体価は初診時よりも低下する傾向が 認められた。病悩期間， $\mathrm{T}_{4}$ 值，TSH 值および初診時の MCHA 抗体価については，両者に差は 認められなかった。

一過性甲状腺機能低下症が何故起こるかは不明である。しかし, ${ }^{131} \mathrm{I}$ 摂取率や $\mathrm{T}_{3}$ 值が比較的高 く, TSH に反応する甲状腺ろ胞の残存が示唆されることから, 組織学的には甲状腺機能低下症を 示す橋本病の $3 つ の$ 組織像 ${ }^{13)}$ のち, 高度の線維化を伴ら萎縮性変化の強い型や, 万胞の退行変性 の強い型では機能が回復するとは考えにくく， ろ胞構造の残存度の高い増殖性変化型であろうこと は充分推察される。そして，この組織型をもつ GHT にヨード摄取量の変化や免疫状態の変化な どの要因が加わることによって，一過性の甲状腺機能低下症が惹起されるものと考光られる。

\section{結 論}

1） GHT の甲状腺機能の経過は，従来考兄られていたほど機能低下症に向からものではなく，機 能低下から回復する症例は約 $30 \%$ に認められる。

2） GHT では MCHA 抗体価および TGHA 抗体価が高いほど甲状腺機能低下症の比率は高く なる。

3） GHT では TGHA 抗体価が高いほど予後の甲状腺機能が低下する傾向が強いが，MCHA 抗体価においてはその傾向は認められない。

4）一過性甲状腺機能低下症の GHT は，永続的機能低下症に比べ若年で， $T_{3}$ 值は高く, TGHA 抗体価は低值で, MCHA 抗体価は減少する傾向が認められる。 


\section{文献}

1) Aho K., Gordin A., Palsuo T., Takala J.: Development of thyroid autoimmunity. Acta Endocrinol. 108; 61-64, $1985 . \quad 2)$ Amino N., Miyai K., Onishi T., Hashimoto T., Arai K., Ishibashi K., Kumahara Y.: Transient hypothyroidism after delivery in autoimmune thyroiditis. J. Clin. Endocrinol. Metab. 42, 296-301, 1976.

3) Amino N., Kuro R., Tanizawa O., Tanaka F., Hayashi C., Kotani K., Kawashima M., Miyai K., Kumahara Y.: Changes of serum anti-thyroid antibodies during and after pregnancy in autoimmune thyroid diseases. Clin. Exp. Immunol. 31; 30-37, 1978. 4) Amino N., Mori H., Iwatani Y., Tanizawa O., Kawashima M., Tsuge I., Ibaragi K. ,Kumahara Y., Miyai K.: High prevalence of transient post-partum thyrotoxicosis and hypothyroidism. N. Engl. J. Med. 306, 849-852, 1982.

5) Gordin A. , Lamberg B. A.: Spontaneous hypothyroidism in symptomless autoimmune thyroiditis. Clin. Endocr. 15, $537-543,1981$ 6) Greenberg A. H. , Czernichow P., Hung W., Shelley W., Winship T., Blizzard R. M.: Juvenilechronic lymphocytic thyroiditis; Clinical laboratory and histological correlations. J. Clin. Endocr. 30; 293-301, $1970 . \quad 7$ Hayashi Y., Tamai H., Fukata S., Hirota Y., Katayama S., Kuma K., Kumagai L. F., Nagataki S.: A long term clinical, immunological, and histological follow-up study of patient with goitrous chronic lymphocytic thyroiditis. J. Clin. Endocrinol. Metab. 61, 1172-1178, 1985. 8) Hawkins B. R., Cheah P. S., Dawkins R. L., Whittingham S., Mackay I. R., Welborn T. A.: Diagnostic significance of thyroid microsomal antibodies in randomly seleted population. Lancet 15; 1057-1059, 1980.

9）稗田正志：慢性甲状腺炎の機能 と穿刺吸引細胞診による細胞像との相関に関する研究。日内分泌会誌５6； 895-907， 1980. 10) How J., Khir A. S. M., Bewsher P. D.: Spontaneous remission of hypothyroidism due to Hashimoto's thyroiditis. Lancet 23, 427, 1980.

11) Lazarus J. H. , Burr M. L., McGregor A. M., Weetman A. P., Ludgate M., Woodhead J. S., Hall R.: The prevalence and autoimmune thyroid disease in elderly. Acta endocrinol. 106; 199-202, 1984. 12) Maagoe H., Reintoft I., Christensen H. E., Simonsen J., Mogensen E. F. : Lymphocytic thyroiditis. Acta med. Scand. 202; 469-473, 1977.

13）森 徹, 石原 隆, 高山英世：原発性甲状腺機能低下症の成因ならびに病態に関する研究。 厚生省特定疾患自己免疫疾患調査研究班昭和54年度研究業績；296-299，1979.

14）野津和巳, 桜美武彦, 平田正名, 後藤康生, 野手信哉, 野津吉友, 国司博行, 遠藤治郎：特 定集団における抗甲状腺抗体価と血清TSH。日内分泌会誌 $59 ； 230-240 ， 1983$.

15) Papapetrou P. D., Lazarus J. H., MacSween R. N. M., Harden R. M.: Long-term treatment of Hashimoto's thyroiditis with thyroxine. Lancet 18, 1045-1048, 1972.

16) Portman L., Hamada N., Heinrich G., Degroot L. J.: Anti-thyroid peroxidase antibody in patients with autoimmune thyroid disease: possible identity with antimicrosomal antibody. J. Clin. Endocrinol. Metab. 61; 1001-1003, 1985.

17) Pulvertaft R. J. V., Doniach D., Roitt I. M. : The cytotoxic factor in Hashimoto's disease and its incidence in other thyroid disease. Br. J. Exp. Pathl. , 42; 496-503, 1961.

18) Rallison $\mathrm{M}$. 
L., Dobyns B. M., Keating F. R., Rall J. E., Tyler F. H. : Occurrence and natural history of chronic lymphocytic thyroiditis inchildhood. J. Pediatr. 86, 675-682, 1975.

19) Riddervold F.: Natural course of intermittent chronic autoimune thyroiditis. Acta Endocrinol. 105, 46-48, 984.

20) Sato T., Takata I., Taketani T., Saida K., Nakajima H.: Concurrence of Graves disease and Hashimoto's thyroiditis. Archives of Disease in Childhood 52; 951-955, 1977.

21) Saxena K. M., Crawford J. D.: Juvenile lymphocytic thyroiditis. Pediatrics Dec. 917-926, 1962.

22）棚橋 忍,

長井考太郎, 高桑 薰, 亀谷正明, 時光直樹, 古川和夫, 小林 勇: 慢性甲状腺炎の自然歴に関す る疫学的研究。高山赤十字病院紀要 $9 ; 3-8,1985$.

23）鳥塚莞爾：甲状腺疾患患者実 態調査の集計報告。橋本病調查研究班, 昭和51年度研究業績 ; $1-4,1976$.

24) Tunbridge W. M. G., Brewis M., French J. M., Appleton D., Bird T., Clark F., Evered D. C., Evans J. G., Hall R., Smith P., Stephenson J., Young E.: Natural history of autoimmune thyroiditis. Br. Med. j. 282; 258-262, 1981.

25) Vickery A. L., Hamlin E., Jr. : Struma lymphomatosa (Hashimoto's thyroiditis). N. Engl. J. Med. 264, 226-229, 1961. 26) Wasserman J., Stedingk L. V., Perlmann P., Jonsson J.: Antibody-induced in vitro lymphocyte cytotoxicity in Hashimoto thyroiditis. Int. Arch. Allergy 47; 473-482, 1974.

27）山本蒔子, 海瀬和郎, 海瀬信子, 吉田克己, 桜田俊郎, 斎藤愼太郎：橋本病におけるョード 有機化障害。日内分泌会誌 56；1535-1547，1980. 28） Yamamoto M., Kaise K., Kitaoka H., Yoshida K., Kaise N., Fukazawa H., Sakurada T., Saito S., Yoshinaga K. : Recovery of thyroid function with a decreased titer of antimicrosomal antibody in a hypothyroid man with Hashimoto's thyroiditis. Acta Endocrinol. 102; 531-534, 1983.

29) 山本蒔子,

斎藤㥀太郎, 桜田俊郎, 海瀬和郎, 海瀬信子, 吉田克己, 深澤 洋, 鈴木道子, 野村 隆, 板垣 洋一, 吉永 馨: 4回の一過性甲状腺中毒症を反復した silent thyroiditis の1例に㧍ける抗マイク ロゾーム抗体, 血清サイログロブリンおよび TSH 結合阻害免度グロブリンの変動。日内分泌会 誌, 60; 939-949, 1984.

30) Yoshinari M., Okamura K., Tokuyama T., Shiroozu A., Nakashima T., Inoue K., Omae T.: Clincal importance of reversibility in primary goitrous hypothyroidism. Br. Med. J. 287, 720-722, 1983.

31) Yosida H., Amino N., Yagawa K., Uemura K., Satoh M., Miyai K., Kumahara Y.: Association of serum antithyroid antibodies with lymphocytic infiltration of the thyroid gland; Studies of seventy autopsied cases. J. Clin. endocrinol. Metab. 46；859-862, 1978. (受付日 : ' 89. 1.17) 